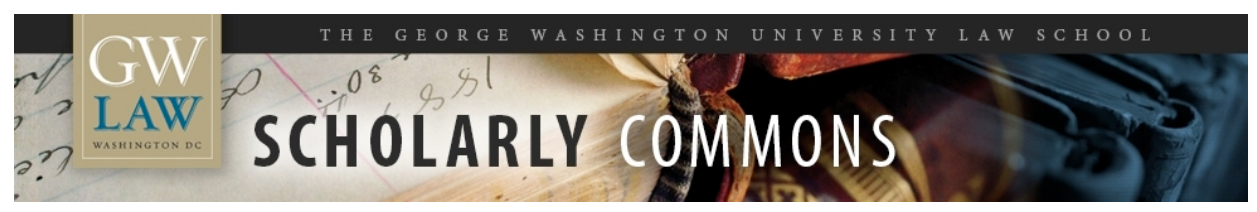

\title{
How to Make the Much-Needed Employee Free Choice Act Politically Acceptable
}

Charles B. Craver

George Washington University Law School, ccraver@law.gwu.edu

Follow this and additional works at: https://scholarship.law.gwu.edu/faculty_publications

Part of the Law Commons

\section{Recommended Citation}

Craver, Charles B., "How to Make the Much-Needed Employee Free Choice Act Politically Acceptable" (2010). GW Law Faculty Publications \& Other Works. 473.

https://scholarship.law.gwu.edu/faculty_publications/473

This Article is brought to you for free and open access by the Faculty Scholarship at Scholarly Commons. It has been accepted for inclusion in GW Law Faculty Publications \& Other Works by an authorized administrator of Scholarly Commons. For more information, please contact spagel@law.gwu.edu. 


\title{
HOW TO MAKE THE MUCH NEEDED EMPLOYEE FREE CHOICE ACT POLITICALLY ACCEPTABLE ${ }^{1}$
}

\author{
By Charles B. Craver ${ }^{2}$
}

\section{INTRODUCTION}

American labor law has reached a critical point. Private sector union membership has declined from 35 percent in $1954^{3}$ to 7.6 percent today. ${ }^{4}$ The National Labor Relations Act (NLRA), ${ }^{5}$ which was enacted in 1935 to protect the rights of employees to form, join, and assist labor organizations and to select exclusive bargaining agents to negotiate their basic terms of employment, has become an outdated and anemic statute. When the NLRA was passed, the U.S. was a mass production economy dominated by relatively large corporate employers most of whose employees desired union representation. The existing American Federation of Labor (AFL), which consisted primarily of trade unions representing skilled craft workers, did not know how its union affiliates could effectively organize industrial bargaining units consisting of skilled, semi-skilled, and unskilled workers. It formed the Committee for Industrial Organization to develop a strategic plan. AFL leaders hoped to organize employees in the automobile,

${ }^{1}$ Copyright 2009 by Charles B. Craver.

${ }^{2}$ Freda H. Alverson Professor, George Washington University Law School. J.D., 1971, University of Michigan; M. Indus. \& Lab. Rels., 1968, Cornell University School of Industrial \& Labor Relations; B.S., 1967, Cornell University.

3 See MICHAEL GOLDFIELD, THE DECLINE OF ORGANIZED LABOR IN THE UNITED STATES 10 (1987).

${ }^{4}$ See Michael Rose, Unions Added 428,000 Members in 2008 As Membership Rate Climbed to 12.4 Percent, BNA/DAILY LAB. REP. No. 17, Jan. 29, 2009, at AA-1.

${ }^{5} 49$ Stat. 449 (1935), 29 U.S.C. $\S § 151$ et. seq. (2000). 
steel, rubber, and electrical manufacturing industries and divide those individuals among different trade unions. When it became clear to union leaders on the Committee for Industrial Organization that such a system would not work well for industrial workers, they withdrew from the AFL and formed the Congress of Industrial Organizations (CIO). CIO leaders quickly established the United Automobile Workers Union, the Steelworkers Union, the Rubber Workers Union, and the Electrical Workers Union, and these new entities began to organize the manufacturing facilities in their respective industries. Although many employers initially opposed union organization, both the new Labor Board and strong union efforts overcame employer opposition. The vast majority of industrial workers desired a collective voice, and they selected industrial unions to represent them. From the enactment of the NLRA in 1935 until the Taft-Hartley Act amendments in 1947, labor organizations could obtain Labor Board certification through either secret ballot elections or "any other suitable method" to determine if a majority or workers in an appropriate bargaining unit desired a collective voice. In many cases, once it became clear that a majority of employees in particular bargaining units had signed authorization cards designating specific unions as their bargaining agents, employers voluntarily extended recognition to those labor organizations without the need to utilize the Labor Board election process.

During the 1940s and 1950s, competition between AFL and CIO affiliates was significant, and private sector union membership grew from 15 percent in 1935 to 35 percent in $1955 .{ }^{6}$ At that time, AFL and CIO unions decided to reunite in the AFL-CIO. ${ }^{7}$

6 See PAUL WEILER, GOVERNING THE WORKPLACE: THE FUTURE OF LABOR AND EMPLOYMENT LAW 8-9 (1990). 
Despite recent predictions by some persons opposed to changes in the current labor laws suggesting that increased union membership would greatly increase unemployment, the U.S. did not experience such a problem when unions represented over one-third of the labor force. What we did see during that period was a willingness of employers to share firm success with workers in the form of generous wages and fringe benefits, creating a sizable blue-collar middle class. Nonetheless, corporate leaders were becoming concerned about diminishing profits caused by increased labor costs generated through the collective bargaining process. ${ }^{8}$ As a result, a growing number of unorganized firms decided to work harder to prevent the unionization of their employees.

American business leaders also engaged in political activity to limit the rights and economic power possessed by labor organizations and their supporters. In 1947, they induced Congress to enact the Labor Management Relations Act (LMRA) ${ }^{9}$ amendments to the NLRA. These statutory changes prohibited a number of unfair labor practices by labor organizations, and restricted the capacity of unions to employ secondary activity to enhance their bargaining power vis-à-vis primary employers. The LMRA amendments ended the right of the Labor Board to certify bargaining agents except through secret ballot elections, and eliminated the ability of labor organizations to control the supply of labor through closed shop agreements that required employers to hire only persons

\footnotetext{
${ }^{7}$ See, Charles B. Craver, The Labor Movement Needs a Twenty-First Century Committee for Industrial Organization, 23 HOFSTRA LAB. \& EMPL. L.J. 69 (2005).

8 See Craig A. Olson \& Brian E. Becker, The Effects of the NLRA on Stockholder Wealth in the 1930s, 44 INDUS. \& LAB. REL. REV. 116, 123 (1990) (indicating that business experts estimated that the enactment of the NLRA and the resulting unionization of millions of workers caused a 15.9 percent decline in shareholder wealth).

${ }^{9}$ Pub. L. No. 80-101, 61 Stat. 136 (1947), commonly known as the Taft-Hartley Act.
} 
already members of unions. ${ }^{10}$ Under the LMRA amendments, new employees could only be required to become union "members" after the thirtieth day of their employment, ${ }^{11}$ and such individuals were only obliged to become "financial core" members - they had to tender the initiation fee and monthly dues, but did not have to become actual union members. $^{12}$

Business groups induced Congress to further narrow worker and union rights in the 1959 Labor Management Reporting and Disclosure Act (LMRDA) ${ }^{13}$ amendments to the NLRA. These statutory changes expanded the scope of proscribed secondary activity and outlawed many forms of organizational and recognitional picketing. ${ }^{14}$ The LMRDA also regulated internal union affairs, required the filing of annual financial reports with the Department of Labor, and imposed fiduciary obligations on union officials.

Corporate opposition to unions grew more expeditiously during the inflationary years of the 1970s, as cost-of-living adjustment provisions in bargaining agreements required employers to raise wages in proportion to increases in the consumer price index. Many firms demanded concession bargaining that forced labor organizations to accept wage and benefit reductions, while others transferred production to lower wage areas

\footnotetext{
${ }^{10}$ See THEODORE J. ST. ANTOINE,CHARLES B. CRAVER \& MARION G. CRAIN, LABOR RELATIONS LAW: CASES AND MATERIALS $112\left(11^{\text {th }}\right.$ ed. 2005).

${ }^{11}$ See 29 U.S.C. $\S 158(a)(3)(2000)$.

${ }^{12}$ See Union Starch \& Ref. Co., 87 N.L.R.B. 779 (1949), enforced, 186 F.3d 1008 (7 ${ }^{\text {th }}$ Cir. 1951).

${ }^{13}$ Pub. L. No. 86-257, 73 Stat. 519 (1959).

${ }^{14}$ See 29 U.S.C. $\$ \S 8(b)(4) \&(b)(7)(2000)$.
} 
within the U.S. and abroad. Even organized employers began to explore ways to induce their employees to decertify incumbent bargaining representatives.

Although the absolute number of union members increased from 17,000,000 in the mid-1950s to 22,000,000 in 1980, the percentage of non agricultural labor force participants in unions declined from 35 to 23 percent due to the fact that union membership growth did not keep pace with more rapidly expanding labor force growth. ${ }^{15}$ During the 1980s and 1990s, union membership declined both in absolute terms and as a percentage of the nonagricultural labor force. Today, there are only 16.1 million union members, comprising 12.4 percent of labor force participants. ${ }^{16}$ This figure actually masks the continuing decline in private sector union membership, because it includes the 36.8 percent of public sector employees who are union members. When only private sector workers are included, the proportion of workers in unions declines to a mere 7.6 percent.

Various factors have contributed to the significant decline in private sector union membership. ${ }^{17}$ Many manufacturing employees have been displaced by automation and the transfer of production jobs to low wage countries like China. The transformation of the American economy from blue-collar manufacturing jobs to white-collar and service jobs has also eroded areas of traditional union strength. These factors have depleted the

15 See GOLDFIELD, supra note 3, at 10-11 tbls. 1 \& 2 .

${ }^{16}$ See Rose, supra note 4, at AA-1.

17 See HOYT N. WHEELER, THE FUTURE OF THE AMERICAN LABOR MOVEMENT 12-13 (2002); CHARLES B. CRAVER, CAN UNIONS SURVIVE? 3455 (1993). 
ranks of major industrial unions like the Auto Workers, the Steelworkers, the Electrical Workers, and the Chemical Workers.

Does the decline in union membership over the past several decades indicate that employees no longer wish to be represented by labor organizations? The answer is "no." A recent study by Professors Richard Freeman and Joel Rogers found that 87 percent of workers would still like to have some form of collective influence with respect to firm decisions that affect their employment terms and job security. ${ }^{18}$ They appreciate the fact that as at-will employees who can be terminated by their employers at any time for almost any reason that does not contravene established civil rights laws or significant public policies they possess no meaningful bargaining power vis-à-vis their corporate employers. They merely possess the "exit voice" - i.e., they can leave their present employers if they are dissatisfied with their working conditions. Employees recognize the need for a collective voice to influence their employment situations, since changing their employment positions is not an easy task.

If the vast majority of private sector employees would like a collective voice, why have they failed to select bargaining agents to further their interests? They fear employer retaliation if they take such action. Corporate employers are vehemently opposed to unionization. They often retain the services of labor relations consultants or aggressive law firms to oppose union organizing campaigns. Employers may post anti-union messages on firm bulletin boards, send anti-union messages to employees via company email systems, include anti-union statements in employee pay envelopes, and express their

${ }^{18}$ See RICHARD B. FREEMAN \& JOEL ROGERS, WHAT WOREKRS WANT 147 (1999). 
anti union sentiments at "captive audience" speeches which employees may be required to attend. Employers may apply additional pressure by having supervisors talk with small groups of workers about the negative effects of unionization. Although employers may not threaten workers about the possible adverse effects of unionization, they may make “predictions" regarding the likely negative consequences of union selection. ${ }^{19}$

Union organizers do not have the same channels of communication open to them. They do not have access to company bulletin boards, e-mail systems, and pay envelopes. They are generally not permitted to respond to employer captive audience presentations. They can only gain access to firm premises if there are no external communication channels available to them. ${ }^{20}$ While supervisors can disseminate their anti-union messages during actual work time, pro-union employees can only spread their messages when they and other workers are on break. ${ }^{21}$

Unscrupulous employers often terminate visible union supporters during organizing campaigns. ${ }^{22}$ Such overt anti-union conduct generally sends a chilling message to other employees who are contemplating support for organizing unions. The individuals who have been unlawfully discharged are unlikely to be ordered reinstated for a year or two. By then, their remaining colleagues have often voted against unionization, fearing that their selection of bargaining agents would seriously jeopardize their

${ }^{19}$ See NLRB v. Gissel Packing Co., 395 U.S. 575, 577-78 (1969).

${ }^{20}$ See Lechmere, Inc. v. NLRB, 502 U.S. 527 (1992).

${ }^{21}$ See NLRB v. United Steelworkers, 357 U.S. 357 (1958).

${ }^{22}$ See WEILER, supra note 6, at 238-39; Robert J. LaLonde \& Bernard D. Meltzer, Hard Times for Unions: Another Look at the Significance of Employer Illegalities, 58 U. CHI. L. REV. 953, 961-69 (1991). 
continued employment security. The only monetary remedy for such illegal terminations involves back pay awards, and the fired persons have a duty to mitigate their losses during the litigation process before the Labor Board, reducing the final cost to their employers.

Even when labor organizations are able to counteract employer anti-union efforts and gain Labor Board certification, they are not guaranteed bargaining success. The employers involved are only obliged to meet with such unions at reasonable times and seriously discuss the wages, hours, and employment conditions of the relevant employees. They are not required to make concessions or to reach agreements. ${ }^{23}$ As long as they appear to be bargaining in good faith, they can extend the negotiation process indefinitely without tangible results. Even if unions file unfair labor practice charges challenging the good faith nature of their actions, it can take one or two years for final decisions to be issued, and the most they have to fear are cease and desist orders directing them to return to the bargaining table in good faith. There are no monetary remedies imposed upon employers who engage in bad faith bargaining. ${ }^{24}$ In over forty percent of cases newly certified unions are unable to achieve first contracts. ${ }^{25}$ Once it appears to the employees who selected representative unions that those entities are impotent, decertification petitions are often filed and the responsible unions are defeated.

${ }^{23}$ See 29 U.S.C. $§ 8(d)$ (2000) (defining the duty to bargain under the NLRA).

${ }^{24}$ See Ex-Cell-O Corp., 185 N.L.R.B. 107 (1970).

${ }^{25}$ See John-Paul Ferguson \& Thomas A. Kochan, Sequential Failures in Workers' Right to Organize 1 (March 2006) (unpublished manuscript), cited in William B. Gould IV, The Employee Free Choice Act of 2009, Labor Law Reform, and What Can Be Done About the Broken System of Labor-Management Relations Law in the United States, 43 U.S.F. L. REV. 291, 325 (2008). 
Labor supporters in Congress have proposed the Employee Free Choice Act (EFCA) to level the playing field and provide workers with the opportunity to select union representation without significant interference from anti-union employers. ${ }^{26}$ The three principal sections of this statute would: (1) authorize the Labor Board to certify unions as bargaining agents once a majority of employees have signed authorization cards; (2) permit the Labor Board to award treble damage awards when employees are unlawfully terminated during union organizing campaigns; and (3) require mediation and then binding arbitration of first contracts when the negotiating parties are unable to achieve agreements on their own.

Business leaders are vehemently opposed to the card-check certification provision and the first contract arbitration mandate, and they are working diligently to prevent the enactment of the EFCA in its current form. If labor union officials and Democratic supporters of the EFCA refuse to consider possible modifications that might enable them to obtain a cloture vote in the Senate, it is doubtful an actual vote on the merits will result. This article will explore the different provisions of the EFCA and will propose modifications that might make that proposed law more palatable to employers.

\section{CARD CHECK CERTIFICATION}

Many opponents of the EFCA card check certification provisions assert that true industrial democracy can only be preserved by way of traditional secret ballot elections. They equate Labor Board representation elections with general political elections, failing

${ }^{26}$ See Catherine Hollingsworty, House Panel Approves Union Organizing Bill Covering Certification by Authorization Cards, BNA/DAILY LAB. REP. No. 32, Feb. 16, 2007, at AA-1; Karen L. Werner, House Passes Card-Check Organizing Bill, Setting Stage for Showdown in Senate, BNA/DAILY LAB. REP. No. 41, March 2, 2007, at AA-1. 
to acknowledge the undue influence possessed by employers compared to federal, state, and local politicians. When individuals vote in political elections, they do not fear that the outcomes of those elections may directly threaten their future job security. On the other hand, many employers opposing union organizing campaigns expressly or implicitly suggest to their employees prior to Labor Board elections that if unions are selected as bargaining agents, those workers may lose their jobs due to increased labor costs. It should thus be clear that Labor Board elections are not free from such external influence.

When I speak to EFCA opponents who extol the virtue of secret ballot elections, they become quite upset when I suggest that the salaries and bonuses paid to corporate executives should be subject to secret ballot elections by shareholders. While they maintain that secret ballot elections should be required for employees considering the selection of bargaining agents, they do not believe that shareholders should possess the right to vote in secret ballot elections on issues of corporate significance. These persons seem to think that unions have never been allowed to obtain Labor Board certification except through secret ballot elections. They fail to appreciate the fact that the original NLRA authorized the certification of labor organizations based upon signed authorization cards from 1935 until 1947 without significant difficulties.

Supporters of the EFCA maintain that the Labor Board election process is tainted by employer economic power used to intimidate employees who support union campaigns. They assert that reliance upon authorization cards would provide a fairer way to determine if a majority of workers truly desire union representation. EFCA opponents, however, suggest that some individuals may be induced to sign union authorization cards through overt coercion or more subtle forms of social pressure. Overt coercion is clearly 
unlawful and would contravene Section $8(\mathrm{~b})(1)(\mathrm{A})$ of the NLRA, ${ }^{27}$ which prohibits actions by labor organizations that would interfere with the statutorily protected rights of employees. As a result, such behavior rarely occurs. Although it is true that some workers may feel social pressure to sign authorization cards if many of their coworkers support union organizing drives, such social pressure is unlikely to be as significant as the fear of job losses union supporters might have if unions win Labor Board elections. Due to their economic dependence on continued employment, employees tend to be far more influenced by coercive employer tactics than by improper union actions.

Employer groups have challenged the EFCA based upon the claim that unions would be able to obtain authorization card signatures from employees before targeted employers could explain the negative aspects of union representation. Some EFCA supporters have suggested that employers have no right to disseminate their views of unions during organizing campaigns, but such assertions ignore two critical considerations. First, corporate employers enjoy First Amendment free speech rights, ${ }^{28}$ and have the right to express their anti-union opinions. Second, employees have the right to appreciate both the pros and cons of unionization. Labor organizers do an excellent job of communicating the benefits they think workers can derive from collective representation. Individual employees opposed to unionization lack any formal platform to

${ }^{27} 29$ U.S.C. $\$ 158(\mathrm{~b})(1)(\mathrm{A})(2000)$.

${ }^{28}$ See NLRB v. Virginia Electric \& Power Co., 314 U.S. 469 (1941) (indicating that employer statements about unions should not be regarded as evidence of unlawful behavior unless, viewed against the "totality of conduct," they are coercive. This concept was added to the NLRA in 1947 by way of Section 8(c), 29 U.S.C. $§ 158$ (c) (2000), which protects the free speech rights of both labor organizations and employers, so long as statements do not contain a threat of reprisal or promise of benefit. 
express their sentiments. If such viewpoints are to be disseminated in an effective manner, targeted employers must be given the opportunity to communicate their opinions to employees being organized.

Employer groups have challenged the EFCA based upon the claim that unions would be able to obtain authorization card signatures from employees before targeted employers could explain the negative aspects of union representation. Most employers learn fairly early about incipient union campaigns from their own employees who mention such drives to supervisory personnel. Nonetheless, labor organizations would still have several days to obtain signatures before employers could gear up their antiunion campaigns and express their sentiments to their employees. To offset this factor, Congress could include a provision in the EFCA that would require labor organizations seeking to obtain bargaining rights through authorization cards to notify targeted employers - and the appropriate regional offices of the Labor Board - of their planned campaigns. The statute could provide that only authorization cards signed after employers have received such notice would be considered when determining whether to extend bargaining rights to the unions involved. To avoid the improper forward-dating of cards actually signed by persons prior to such employer notification, labor organizations could be required to obtain Labor Board imprints in the cards they plan to use when they initially notify the Labor Board office of anticipated organizing campaigns.

In exchange for the right to be notified of incipient union organizing campaigns, Congress might consider the recent proposal by Representative Joe Sestak (D. Pa.) that would require employers to provide unions with the same means of communication being 
used by employers opposing union campaigns. ${ }^{29}$ This approach would allow employees to hear the pros and cons of unionization from both sides, on a relatively equal basis. If employers decide to give captive audience speeches, union supporters would have the right to respond at such sessions. If employers communicate anti-union messages on bulletin boards, e-mail sites, or in documents included in worker pay envelopes, union organizers would have the right to use those same communication channels. If employers have supervisory personnel communicate anti-union sentiments during work hours, union supporters should enjoy the same privilege. It should be difficult for persons who believe in true industrial democracy to argue that employers should be able to use such means of communication without extending similar privileges to union supporters.

Individuals opposed to card check certifications maintain that since some authorization card signers may have been induced to sign such cards due to overt coercion or more subtle social pressure, bargaining rights may be extended to labor organizations that do not actually possess majority employee support. How might this concern be ameliorated? Congress could modify the current EFCA bill to require a weighted majority before bargaining rights could be extended by the Labor Board pursuant to authorization card showings. Unions could be required to sign up 60 or 67 percent of individuals in particular bargaining units before certification could be approved. Such an approach would greatly diminish the likelihood that bargaining rights would be extended to unions that did not actually possess majority worker support.

${ }^{29}$ See Ryan Davis, Bill to Ease Union Organizing Reintroduced, http://employment.law360.com/articles/91030 (March 12, 2009). 
Members of Congress who still believe that only secret ballot elections should be used to grant certification to labor organizations should consider two alternatives. First, statutory provisions could impose monetary fines on employers who threaten union supporters during representation campaigns. At the present time, the only remedy for such conduct consists of cease and desist orders directing offending employers to refrain from such behavior in the future. Meaningful fines would have an appropriate deterrent effect. Second, a provision requiring the Labor Board to conduct representation elections within five or ten days after election petitions are filed would be beneficial. This is the practice followed by labor laws in several Canadian provinces. ${ }^{30}$ Such an approach would significantly shorten the fifty to sixty days most employers currently have to engage in anti-union campaigning prior to Labor Board elections. ${ }^{31}$ Both employers and labor organizations would have sufficient time to disseminate their pro or anti union messages, and such expedited elections would decrease the ability of employers to coerce potential voters through express or implicit job loss statements.

Senators Arlen Specter and Mark Pryor have been contemplating an alternative approach that might satisfy the concerns of both sides. They would authorize the Labor Board to conduct certification elections by way of mail-in ballots. To satisfy union demands for a more expeditious certification determination process, the Labor Board could be required to send out the mail-in ballots immediately after labor organizations have petitioned for certification. This could provide election results within ten days after petitions have been filed. It would also assuage employer concerns regarding employee

${ }^{30}$ See Gould, supra note 25, at 317.

${ }^{31}$ See id. at 315. 
free choice, by allowing employees to decide whether to vote for or against union representation in the secrecy of their own homes.

\section{TREBLE DAMAGE AWARDS FOR UNLAWFULLY TERMINATED UNION SUPPORTERS}

The most potent weapon available to anti-union employers involves the overt discharge of open union supporters. Such conduct has an immediate chilling effect, and it discourages other employees from engaging in public acts supporting organizing campaigns. At the present time, illegally terminated workers have only two Labor Board remedies. After one or two years of unfair labor practice litigation before administrative law judges, the Labor Board, and courts of appeals, such persons are awarded back pay covering their periods of unemployment and the responsible employers are directed to offer them reinstatement to their former positions. By this time, the fired individuals have suffered both emotional and economic losses, and their former colleagues have been greatly intimidated.

A provision in the proposed EFCA would authorize the Labor Board to award treble damages to union supporters unlawfully discharged during union organizing drives. Such a remedy would have two benefits. The additional money involved would help to compensate the adversely affected persons for their lost earnings and the emotional distress they have sustained, and it would have a greater deterrent impact on employers considering such actions than the mere awarding of back pay.

What else could Congress do to ameliorate the significant impact of unlawful terminations of union supporters - and eliminate or at least ameliorate the need for increased monetary penalties in such situations? It could amend the NLRA to require the Labor Board to petition district courts for temporary restraining orders directing the 
immediate reinstatement of individuals the Board believes have been clearly discharged because of their protected actions supporting union organizing campaigns. They are thus returned to their work environments while the unfair labor practice proceedings unfold. At the present time, the Labor Board is obliged to seek such mandatory injunctive relief under Section $10(1)^{32}$ when labor organizations engage in secondary activity in violation of Section $8(b)(4)^{33}$ or organizational or recognitional picketing in violation of Section 8(b)(7). ${ }^{34}$ On the other hand, when employers commit unfair labor practices, the Labor Board may seek preliminary injunctions under Section $10(\mathrm{j})^{35}$ to maintain the status quo while the actual unfair labor practice charges are being litigated. The Board uses its 10(j) injunctive remedy sparingly. This is why it takes so long for discriminatees to obtain reinstatement orders. If Congress were to add Section 8(a)(3) discharges to Section 10(1), unlawfully terminated union supporters would gain expeditious reinstatement. This would be highly beneficial for those individuals, and it would minimize the continuing negative impact of their public terminations on their coworkers.

\section{FIRST CONTRACT ARBITRATION}

The most controversial provisions in the EFCA are those pertaining to labor organizations that have been certified by way of card checks or secret ballot elections but that have been unable to obtain initial contracts through the collective bargaining process. If no agreement is reached within ninety days, under the EFCA the Federal Mediation

\footnotetext{
3229 U.S.C. $\$ 160(1)(2000)$.

3329 U.S.C. $§ 158(b)(4)(2000)$.

${ }^{34} 29$ U.S.C. $\S 158(b)(7)(2000)$.

3529 U.S.C. $\S 160(j)(2000)$.
} 
and Conciliation Service is to provide neutral facilitation services. If after thirty days of mediation no agreement is obtained, the matter is to be resolved through binding interest arbitration. The employer and the labor organization would present their economic data and relevant arguments to either a single arbitrator or a three member arbitration panel that would be empowered to determine the initial wages, hours, fringe benefits, and working conditions to govern the parties' initial year.

One preliminary matter should be considered that could reduce the number of cases that might be sent to arbitration. When unions are now certified by way of secret ballot Labor Board elections, the affected employers often refuse to acknowledge the validity of the Board certification orders. They refuse to bargain with the newly certified labor organizations, forcing those entities to seek relief through Section $8(a)(5)^{36}$ refusal to bargain charges. It can take a year or two for these cases to be resolved through administrative law judge, Labor Board, and Court of Appeal proceedings. By that time, employees who supported unionization have become cynical regarding the efficacy of NLRA protections, and the representative unions have begun to view the dilatory employers quite negatively. As a result, when the parties finally sit down to bargain, the setting is quite contentious. The likelihood they will successfully negotiate first contracts is slight.

What might Congress do to minimize the impact of such frequently unmeritorious delays? It could amend Section 10(1) to require the Labor Board to seek temporary restraining orders directing employers to recognize and bargain with newly certified labor organizations while the Section 8(a)(5) charges are being litigated, whenever the Board

3629 U.S.C. $\S 158(a)(5)(2000)$. 
has preliminarily determined that the employers are engaged in clearly unjustified refusals to honor the union certifications. If employers were required to bargain with unions immediately following their Labor Board certifications, the likelihood that contracts could be obtained through the collective bargaining process would increase. This would obviate the need for first contract arbitration.

If the first contract arbitration provision is retained in the EFCA, economically weak labor organizations may decide that they have nothing to lose by invoking such procedures. Since it would be difficult to imagine arbitrators awarding unions benefits less beneficial than those being offered by employers at the bargaining table, union leaders could reasonably believe that arbitral procedures would have to generate benefits above those offered by the employers. As a result, the availability of interest arbitration would diminish the probability that unions would bargain in complete good faith following their initial certifications.

If first contract arbitration is to be employed to resolve bargaining failures after 120 days, what standards should be imposed on the final arbiters? Should they be authorized to dictate any initial terms they think appropriate or should their discretion be circumscribed? It is difficult for me to imagine external arbitrators determining the specific wages, fringe benefits, hours, and working conditions to cover newly unionized employees. Should they adopt standards consistent with other similar firms in the U.S. or the immediate geographical area or should they consider the practices of local firms in diverse lines of work? What health care and pension coverage should be imposed? What forms of union security should they mandate? What management rights clauses should be included? If Congress decides to include a first contract arbitration provision in the 
EFCA, it should include something to constrain arbitrator discretion. It should require arbitrators to choose between the final offers tendered by the employers and labor organizations based upon the reasonableness of the relevant terms. This could be done on a total contract basis or on an issue-by-issue basis. I would suggest the issue-by-issue approach to enable arbitrators to select - issue-by-issue - the more reasonable of the proposals advanced by labor and management. This approach would encourage bargaining parties to make reasonable proposals to each other, which might obviate the need for arbitration. When mutual accords could not be achieved, this procedure would limit the economic discretion possessed by arbitrators.

For members of Congress who find binding interest arbitration too extreme a dispute resolution mechanism, they might consider non-binding arbitration where arbitrators would conduct hearings, determine the relevant facts, and make non-binding, but public, recommendations to the parties. The labor and management representatives would then return to the bargaining table. The public arbitral findings and suggestions would put pressure on the negotiating parties to seek agreements in line with the arbitral recommendations.

\section{CONCLUSION}

The NLRA no longer protects the rights of employees who desire union representation. Despite the fact the vast majority of workers would like some form of collective voice to counterbalance the economic power possessed by their corporate employers, most have been unable to achieve such representation. Employers have a substantial advantage over organizing unions due to both their economic power and the fact they have unlimited means to communicate their anti-union messages to employees. 
Business success is attributable to three critical groups: (1) the shareholders who provide the investment capital; (2) the managers who direct the business; and (3) the employees who produce the goods or services. Over the past several decades, rank-and-file workers have become the junior partners in firm success, but the junior partners in firm failure. ${ }^{37}$ Congress should seriously consider some form of EFCA that would level the playing field and guarantee employees the right to select bargaining representatives if they wish to have a collective voice.

The use of authorization cards to obtain union certification would make it easier for labor unions to organize employees. To minimize the impact of union coercion or social pressure, unions could be required to sign up 60 or 67 percent of unit personnel before they could be certified. To guarantee union supporters an equal opportunity to spread their pro-union message, employers could be required to provide union supporters with the same means of communication they employ to spread their anti-union messages. If Congress continues to believe in the sanctity of secret ballot elections, they could amend the NLRA to require the Labor Board to conduct representation elections within five or ten days after election petitions are filed. This might even be accomplished by directing the Labor Board to use mail-in ballots that could be sent to eligible employees shortly after certification petitions have been filed.

To limit the tendency of employers to unlawfully terminate open union supporters during organizing campaigns, Congress could authorize treble back pay awards to persons fired in this manner. They could alternatively amend Section 10(1) to require the

${ }^{37}$ See Charles B. Craver, The American Worker: Junior Partner in Success and Senior Partner in Failure, 37 U.S.F. L. REV. 587 (2003). 
Labor Board to seek preliminary injunctive relief reinstating individuals who appear to have been discharged illegally while their unfair labor practice proceedings unfold. Congress could similarly amend Section 10(1) to require the Labor Board to seek such preliminary injunctive relief in cases where unions have obtained certification but the employers have refused to honor those certifications. Such firms would be directed to recognize and bargain with the newly certified labor organizations while the underlying refusal to bargain charges are being litigated.

The most controversial part of the EFCA involves the provisions that would mandate first contract arbitration after 120 days of unsuccessful bargaining. This would constitute a significant change in existing American labor law and it would ignore the fact that newly certified unions often fail to obtain first contracts. To limit arbitral discretion if these procedures are adopted, Congress should direct arbiters to select between the final offers of labor and management on an issue-by-issue basis. They could alternatively require only non-binding arbitration in which the arbitrators would decide the underlying factual and economic issues and make public recommendations the parties would not be obliged to accept, but would have to consider when they returned to the bargaining table. 